\title{
AN UPDATE ON COLOR IN GEMS. PART 1: INTRODUCTION AND COLORS CAUSED BY DISPERSED METAL IONS
}

\author{
By Emmanuel Fritsch and George R. Rossman
}

Studies concerning the origin of color in gem materials have grown in sophistication in recent years, so that much new information is now available about natural color and its possible modification by various treatment processes. This three-part series of articles reviews our current understanding of gemstone coloration. The first part summarizes the factors that govern the perception of color, from the source of light to the human eye, and then examines in detail the role of one color-causing agent, dispersed metal ions, in the coloration of many gem materials, including ruby and emerald. The second part will explore charge-transfer phenomena and color centers as the cause of color in gems such as blue sapphire and Maxixe beryl. The series will conclude with colors that can be explained using band theory and physical optics, such as the play-of-color in opal and the blue sheen of moonstone feldspars.

\footnotetext{
ABOUT THE AUTHORS

Dr. Fritsch is research scientist at the Gemological Institute of America, Santa Monica, California Dr. Rossman is professor of mineralogy at the California Institute of Technology, Pasadena, California.

Acknowledgments: E.F. wishes to thank Professor Georges Calas, of the University of Paris VII, for his support in writing the original French version of this article. Special appreciation is due to Pat Gray for typing and correcting the "French accent" of the original manuscript. Thanks to Laurel Bartlett, John Hummel, and James Shigley for their constructive comments.

(1) 1987 Gemological Institute of America
}

$\mathrm{T}$ he origin of color in minerals in general and gem minerals in particular has been investigated with increasing sophistication in recent years. The new information provided by this research demonstrates that several mechanisms can contribute to the coloration of a single gem. Moreover, recent concerns about gemstone enhancement, which usually implies color enhancement, make it necessary to understand what happens during treatment and what changes in appearance can and cannot be achieved.

A strong interest in minerals arose early in history, because they are among the few natural materials that can permanently retain color, unlike flowers and plants, which fade or change with time. Colorful minerals such as iron oxides became the basic pigments of early paintings. Eventually, colored stones were cut and polished so they could be worn for adornment. From antiquity into the 18 th century, color was also at the center of numerous superstitions, legends, and even "medical" treatments involving gems and minerals. Yellow stones, for example, were supposed to cure jaundice, and green stones were believed to soothe the eyes (Kunz, 1913).

As mineralogy became a science at the turn of the 19 th century, color was used as a common indication in the identification of minerals. Soon, though, people discovered that crystals of the same mineral species could vary in color, and they began to surmise that some hues were related not to the mineral but to specific impurities /figure 1). Goethe, for example, was one of the first to relate the amethyst coloration in quartz to its iron content. The simple correlation between a certain color (e.g., "emerald green") and a given element (chromium) works to some extent, but modern research has shown that a number of very different processes can result in a similar color (Nassau, 1983).

Extensive collections of mineral and gemstone spectra 


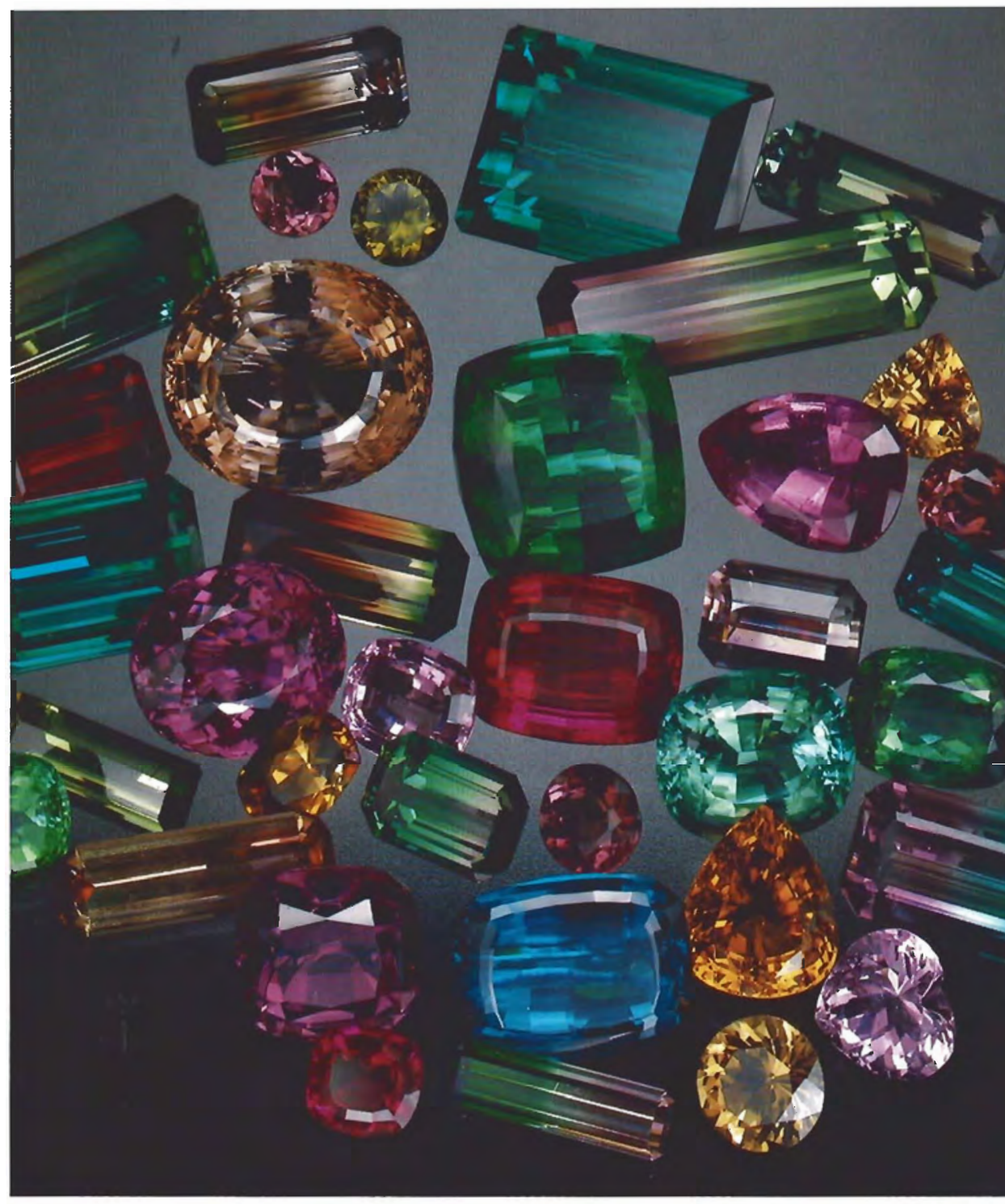

Figure 1. A number of different mechanisms are responsible for the variety of colors found in tourmaline. For example, the blue color of indicolite is caused by dispersed $\mathrm{Fe}^{2+}$, but charge transfer between iron ions often contributes to the color of the green varieties. This article explains the influence of dispersed metal ions in the color of many different gem materials; the other two articles in this series will examine other causes of color such as charge transfer. Photo $\mathbb{C}$ Harold $\Theta$ Erica Van Pelt.

were assembled in the Soviet Union by a variety of researchers during the 1940s to 1960s. A theory developed in 1929 to explain color in crystalline solids was first applied to mineralogy in the late 1950s and was widely employed to explain color in minerals in the 1960s. In the U.S., the application of the science of color to minerals experienced its major impetus around 1970, with the publication of Mineralogical Applications of Crystal Field Theory, by Roger Burns. At approximately the same time, the optical properties of various synthetic colored crystals were described (e.g., Kittel, 1956; Farge and Fontana, 1979; Bill and Calas, 1978). Some long-standing and widely accepted explanations among gemologists were reevaluated according to new understanding of the origin of color. For example, organic products had long been held to be responsible for the blue coloration of fluorite, as mentioned in the 2nd edition of Webster (1970). In 1978, however, Bill and Calas demonstrated the role of ionizing radiation in generat- ing color in fluorite. Nevertheless, many terms persist (such as "chrome" fluorite from Muzo, Colombia) that originate from erroneous beliefs about the origin of the color ("chrome" fluorite is actually colored by samarium).

In the course of modern research, five basic mechanisms have been identified as causes of color in gem materials: dispersed metal ions, charge-transfer phenomena, color centers, band theory, and physical optics. The purpose of this series of articles is to review the current knowledge of the origin of color in gems /see Fritsch, 1985, for a broader discussion of the cause of color in minerals in generall, illustrating each mechanism with a number of examples and indicating briefly how treatment affects each type of coloration. First, however, it is important to understand the external factors that may influence our perception of the coloration of a gem. Therefore, this initial article examines the role of light and the human eye and then describes the best-known 
cause of color in gem materials: dispersed metal ions.

\section{LIGHT AND THE HUMAN EYE}

Three factors are important in establishing the color of a gemstone: the type of illumination, the stone itself, and the human eye. Depending on whether the light source is incandescent, fluorescent, or the sun, the appearance of a gem may vary considerably. Some gem materials demonstrate a total color change from one type of illumination to another (the "alexandrite effect," as explained, for example, in Farrell and Newnham, 1965). In addition, the stone itself will modify the incoming light in various ways, generally by absorbing part of it and transmitting the remainder. The transmitted light is then received by the human eye and transformed into a color perception by the brain. To understand the origin of color in the object itself, we must first briefly explore the roles of the light source and the human eye.

What Is Light? A prism will separate sunlight into the colors of the rainbow-a juxtaposition of violet, blue, green, yellow, orange, and red. Each of these colors, usually designated as "spectral colors, "represents part of the visible spectrum (figure 2). Light of a particular wavelength carries a given energy - the shorter the wavelength, the higher the energy. The visible range extends, depending on the observer, from about $375 \mathrm{~nm}$ up to $740 \mathrm{~nm}$. In sunlight, higher energy radiations (such as ultraviolet) and lower energy radiations (such as infrared) are also present.

One of the mechanisms that causes color is the absorption by a gemstone of part of the visible wavelengths that are passing through it. Thus, if a stone absorbs mostly red and violet-blue, as is the case with emerald, the light that is not absorbed (i.e., green, plus a little yellow and blue) passes through the stone, which will thus appear green.

As mentioned earlier, the color of some gem materials may be strongly modified when the source of illumination is changed. For example, alexandrite is green in sun (fluorescent) light and red in incandescent (e.g., candle) light. These two light sources contain different proportions of the spectral colors. The flame of the candle has an orange tint, because it is emitting much more yellow, orange, and red than blue. In fact, it is emitting so little blue light that a stone transmitting only blue, such as blue sapphire, will appear

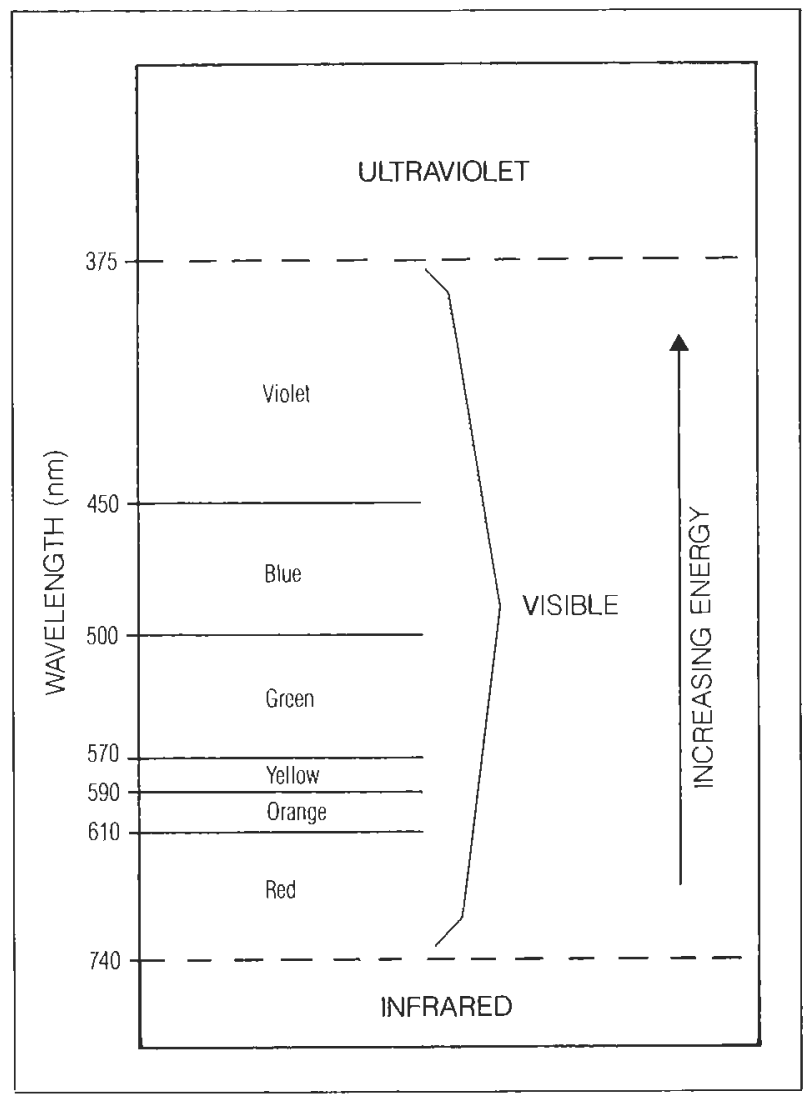

Figure 2. Each of the colors that make up visible light corresponds to a specific wavelength and energy range.

almost black when observed with such illumination. As an early French author stated, "it is the strangest thing in the world to see a magnificent sapphire parure become black in the candle's glimmer" (Pouget, 1752). Fluorescent light, however, emits a much larger proportion of light at the blue end of the visible spectrum and is, therefore, a more desirable source of illumination for blue stones.

The Human Eye and Color. Two classes of lightsensitive cells are present in the retina of the human eye: cones and rods. If the light intensity is low (as in a dimly lit room), there will be no color sensation. Objects appear in shades of gray. This phenomenon is related to the use of the rods, which are responsible for vision under poor lighting and contain only one pigment (see, e.g., Wasserman, 19781.

At higher levels of illumination, color perception involves the cones. Each cone contains one of 


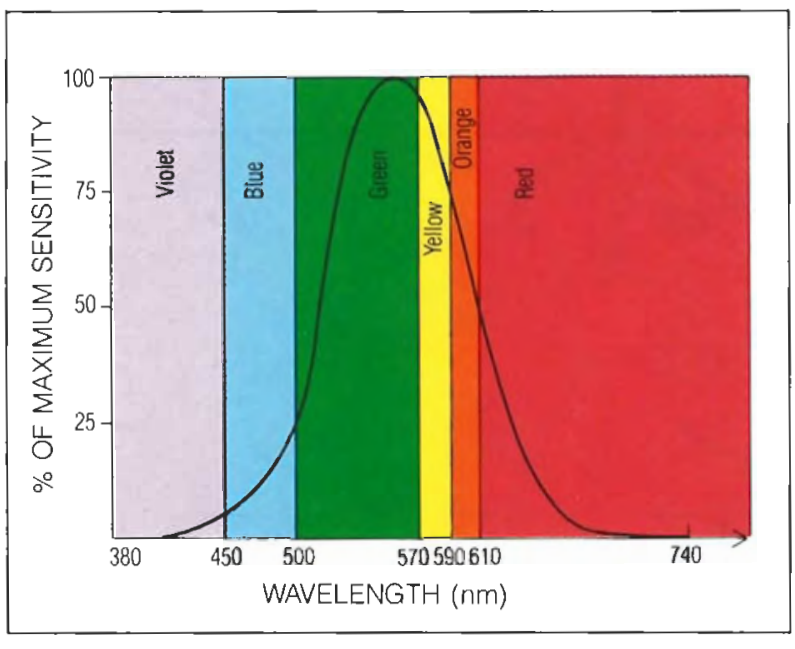

Figure 3. As evident from this graph of the spectral sensitivity of the human eye, a person's greatest sensitivity is to the color green. Adapted from Duplessis (1985).

three fundamental pigments, which have a maximum absorption in the red, the blue, and the green, respectively. The color we perceive is a combination of the responses coming from the three different types of cones, which depend in turn on their levels of reaction to a given light stimulus. The human eye is not equally sensitive to each visible color. Rather, it is most sensitive to green, as shown in figure 3 (Duplessis et al., 1985). It is interesting to note that the peak of this curve coincides with the peak wavelength of the solar radiation at the surface of the earth. In fact, the uneven spectral sensitivity of the human eye has long been viewed as an adaptation to life with sunlight (Nassau, 1983).

\section{THE INTERACTION OF LIGHT WITH GEMSTONES}

Many things can happen to the light entering a cut stone: It can be reflected, refracted, diffracted, scattered, absorbed, or simply transmitted. Although absorption is by far the most important factor in determining color, one must realize that several combinations of these different processes are possible; for example, a colorless (nonabsorbing) gem may acquire color by diffraction (e.g., opal). We will, therefore, describe the numerous causes of absorption in the first two parts of this series, and then, in the last part, will consider the remaining possibilities that influence color. In so doing, we will follow as well an increase in the size of the color-causing agent. Dispersed ions are single atoms, and thus the smallest possible cause of color. Charge-transfer phenomena and the creation of color centers both require small groups of atoms. A much larger cluster of atoms is involved in band theory. Lastly, physical structures of considerable dimension compared to the size of the atom (lamellae, for example) are responsible for colors explained by physical optics. In the case of these large structures, the color is determined primarily by their size and shape; for a few gem materials, texture has a greater impact on color (and phenomena) than does chemical composition.

We will begin this discussion of the causes of color in gemstones by examining how color is induced in gem materials through the absorption of light by dispersed metal ions. "Dispersed" here means that the ions are sufficiently isolated from one another by other types of atoms that they never interact.

\section{COLORS CAUSED BY DISPERSED METAL IONS}

How Does an Ion Absorb Light? An atom consists of a positively charged nucleus and negatively charged electrons, which are in motion about the nucleus. The identity of the atom is determined by the composition of the nucleus. When the number of positive charges in the nucleus is equal to the number of negative charges (electrons) around it, the atom is neutral. When it is not electrically neutral (e.g., when it has an extra electron), it is called an ion. The actual electric charge of the ion is referred to as the valence state, and is symbolized by a sign and a number attached to the symbol of the atom, such as $\mathrm{Cr}^{3}+$ for chromium with three electrons missing, or $\mathrm{O}^{2}$ - for oxygen with two additional electrons. Sometimes a corresponding adjective exists: Ferrous iron is $\mathrm{Fe}^{2+}$ and ferric iron is $\mathrm{Fe}^{3+}$.

Electrons are conveniently represented as moving around the nucleus within specific volumes called orbitals (figure 4). A given number of electrons revolving in a set of orbitals represent a certain energy for this particular ion. Absorption occurs when illumination causes one electron to move from one orbital to another orbital of higher energy. The corresponding change in energy of the ion equals the energy of the light absorbed. This can be illustrated schematically in energy-level diagrams, such as in figure 5 .

When an electron absorbs light it changes its 
Figure 4. These are some orbitals of metal ions that cause color in gem materials. The electrons move around the nucleus

within these volumes of specific shape and direction. Adapted from Fyfe (1964); reproduced with permission.
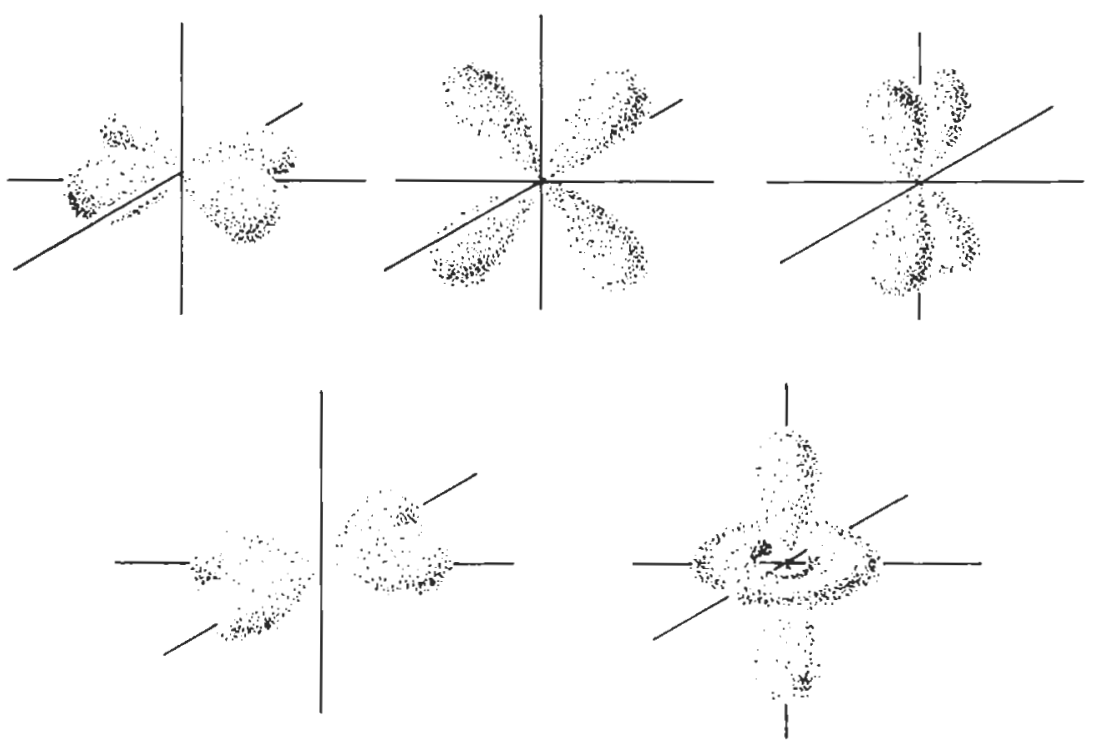

orbital. This process is called a transition, from the ground state (low-energy initial configuration of the electrons) to the excited state (a higher-energy configuration). Figure 5 shows how an absorption band as seen with a hand-held spectroscope relates both to a (more accurate) spectrum recorded on a spectrophotometer and to an energy diagram that indicates the various energy levels involved. When the transmitted light is observed with a hand-held spectroscope, the absorption will give rise to a dark band (the missing wavelengths). With a spectrophotometer, it appears as a broad absorption band on the graph (again, see figure 5).

The excited state is intrinsically unstable, so the electron must return to its normal ground state. Generally, there are two ways for this to happen. The more common way is for the electron to release the energy to the crystal lattice in the form of atomic vibrations (heat). The other way, which can be of great gemological significance, is

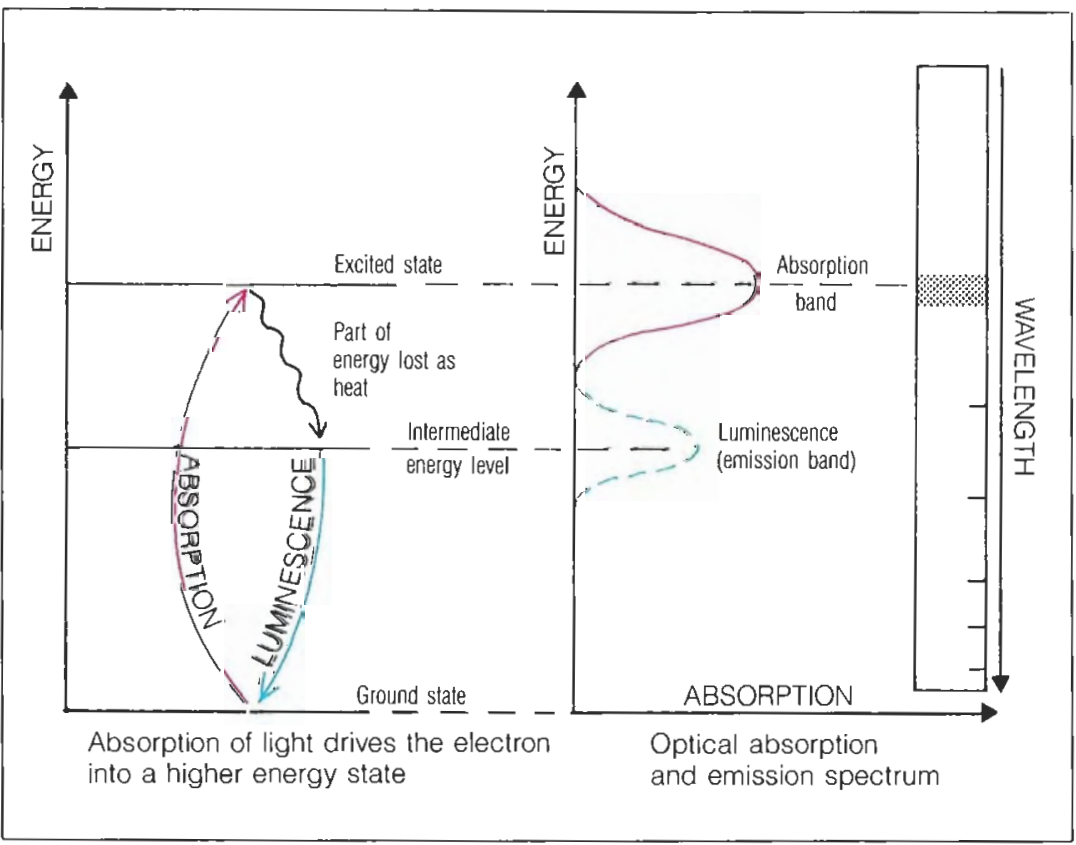

Figure 5. An absorption spectrum as seen in a hand-held spectroscope is compared with that obtained with a research spectrophotometer and the relevant representation of the fundamental mechanics of light absorption. When a crystal absorbs light, electrons are moved from the low energy (ground) state to a higher energy (excited) state. This energy is ultimately lost when the electron returns to its ground state by dissipating the energy either as heat in the crystal or through the emission of light (luminescence). 
luminescence, in which part of the energy acquired in the transition is converted into light emitted by the stone. Since the electron cannot emit more energy than it absorbed, luminescence must occur with an emission of energy equal to or less than that acquired in the absorption, as can be seen in figure 5. This means that the wavelength of luminescence must be equal to or longer than that of absorption. For example, $\mathrm{Cr}^{3}+$ in ruby absorbs in the yellow-green and luminesces in the red. This is also why so many gemstones emit visible (low energy) luminescence when exposed to ultraviolet (high energy) radiation. Absorption in the ultraviolet spectral range results in an emission at a lower energy, that is, in the visible range.

The Identity of the Ion Affects the Color. In actuality, very few ions have the ability to absorb visible light. The ones most commonly encountered in gemstones are the ions of the following elements: titanium $\{\mathrm{T} i\}$, vanadium $(\mathrm{V})$, chromium $(\mathrm{Cr})$, manganese $(\mathrm{Mn})$, iron (Fe), cobalt (Co), nickel $(\mathrm{Ni})$, and copper $(\mathrm{Cu})$. Although a number of other elements can also cause color, such as cerium in some orange cubic zirconia and uranium in heattreated blue zircon, they tend to be restricted to only one' material.

In most cases, different metal ions produce different colors. For example, in general, colors produced by iron will be quite different from those generated by chromium in the same mineral; that is, in spinel, $\mathrm{Fe}^{2+}$ causes a grayish blue color, while $\mathrm{Cr}^{3+}$ causes red. The following examples illustrate the various factors that influence how metal ions give rise to color in gem materials.

The Influence of the Valence State. The valence state of an ion exerts a strong influence on both the hue and the intensity of the color. While a number of valence states are possible for each element, only a few are important in gemology (a reflection of the limited range of chemical conditions that lead to the formation of gem materials). For example, manganese is known in valence states from $\mathrm{Mn}^{0}$ through $\mathrm{Mn}^{7+}$, but it occurs commonly in gems as $\mathrm{Mn}^{2+}$ and $\mathrm{Mn}^{3+}$. Beryl containing $\mathrm{Mn}^{2+}$ exhibits a delicate pink hue (morganite), while $\mathrm{Mn}^{3+}$-containing beryl occurs as bright red /red beryl|, as seen in figure 6. A different charge of the same element generally produces a different hue. In the case of manganese, absorption of light in a material occurs with much greater efficiency if

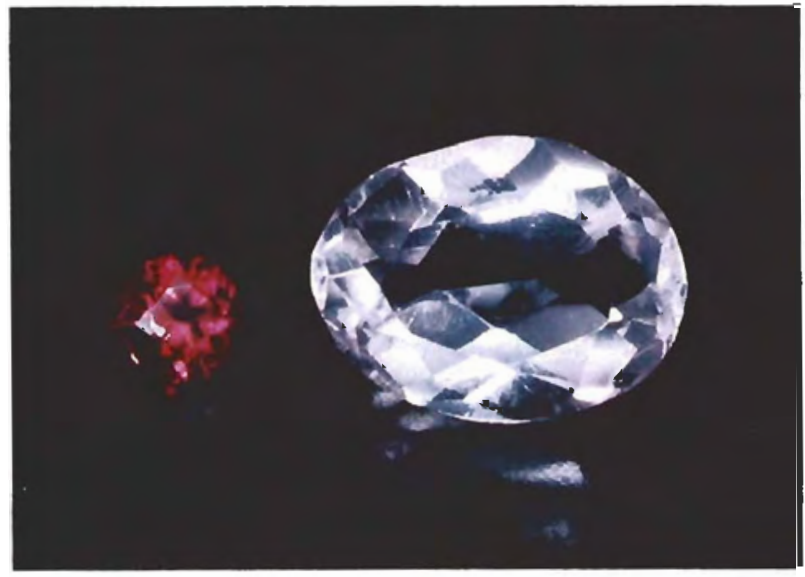

Figure 6. The difference in color intensity between a pink beryl (morganite) from Brazil, colored by $\mathrm{Mn}^{2+}$, and a red beryl from Utah, colored by $\mathrm{Mn}^{3+}$, illustrates the importance of the valence state of the coloring ion. Photo by Shane McClure.

this material contains $\mathrm{Mn}^{3+}$ rather than $\mathrm{Mn}^{2+}$. The reason for such differences has to do with the probability of occurrence of certain transitions, and is explained by certain rules of quantum mechanics, which are beyond the scope of this article. Because $\mathrm{Mn}^{2+}$ (and $\mathrm{Fe}^{3+}$ ) transitions have a low probability of occurrence, they give rise to low-intensity absorptions in the visible range (Burns, 1970) and, consequently, to pale colors. Transitions for $\mathrm{Mn}^{3+}$ and most of the other metal ions occur with much greater probability, producing stronger absorptions and brighter colors.

Various treatment methods can have a powerful influence on the color of gem materials by modifying the valence state of the metal ions they contain. For example, $\mathrm{Fe}^{3+}$ can be changed into $\mathrm{Fe}^{2+}$ by heating in reducing conditions/thus turning green beryl to blue aquamarine; see figure 7 and Nassau, 1984). Irradiation (X-rays, gamma rays, etc.), which can easily remove electrons from atoms, very often produces the opposite effect of heat treatment; for example, it converts $\mathrm{Fe}^{2+}$ into $\mathrm{Fe}^{3+}$, thus turning aquamarine into golden yellow beryl (Goldman et al., 1978). In the production of synthetic amethyst, irradiation is used to transform $\mathrm{Fe}^{3+}$ into the $\mathrm{Fe}^{4+}$ necessary to obtain the purple color (Balitsky and Balitskaya, 1986). In fact, the only way treatment can affect color caused by dispersed metal ions is by modifying the valence state. 


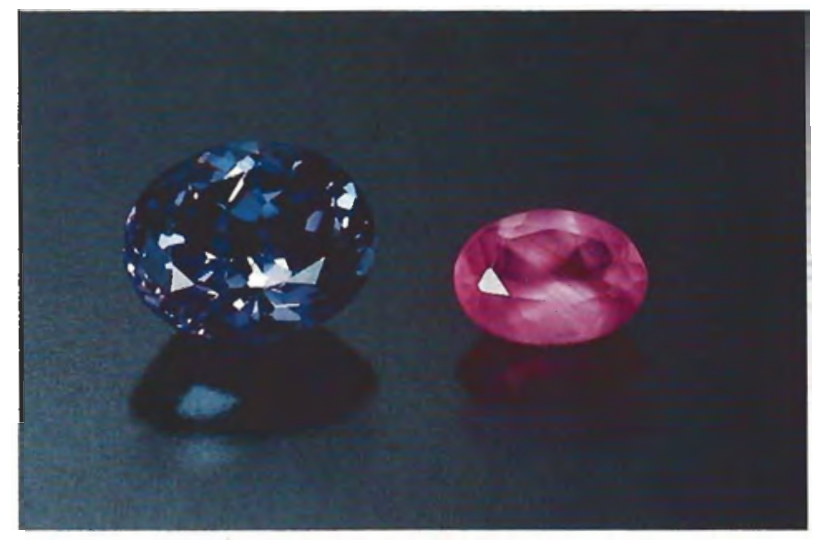

Figure 9. These two stones show the difference in color caused by a difference in coordination: $\mathrm{Co}^{2+}$ is in tetrahedral coordination in this blue spinel, and in octahedral coordination in the pink cobaltocalcite. Photo by Shane McClure.

Figure 8. Three types of ion coordination are commonly found in gem materials: tetrahedral (four neighbors), octahedral (six neighbors), and distorted cubic (eight neighbors). As illustrated here, the garnet structure exhibits all three of these common coordinations (the tetrahedrons are in red, the octahedrons in blue, and the distorted cubic sites in yellow). Adapted from Novak and Gibbs (1971).

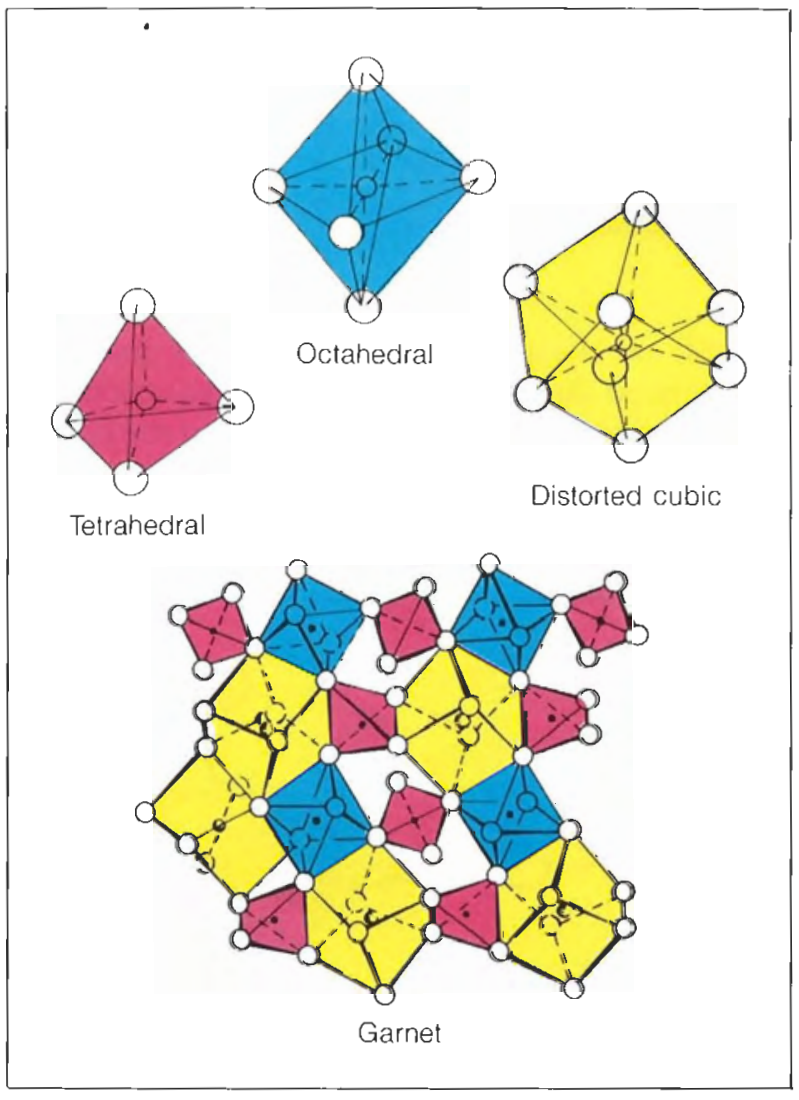

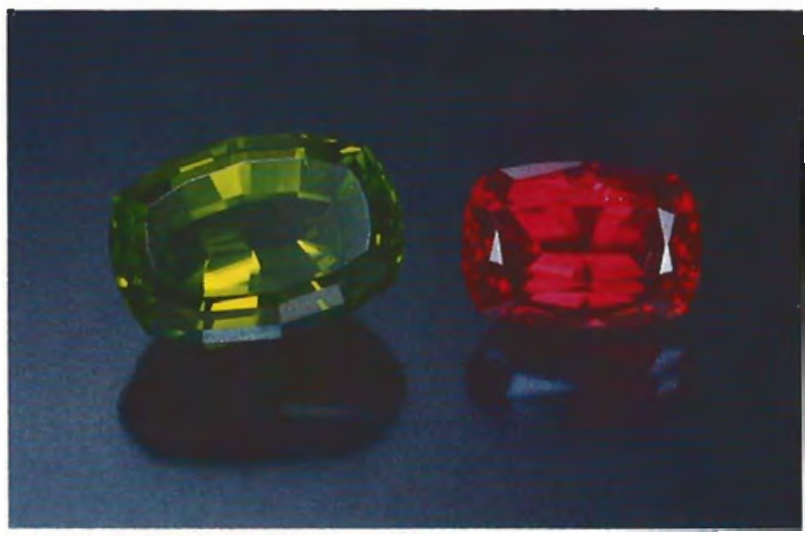

Figure 10. Both green peridot and red pyrope-almandine garnet are primarily colored by $\mathrm{Fe}^{2+}$. The striking difference in color is caused by the difference in ion coordination, which is octahedral in peridot and distorted cubic in garnet. Photo by Shane McClure.

the central metal ion if there is no distortion. In distorted cubic coordination, the central metal ion has eight neighbors; this coordination is gemologically significant only for garnet and zircon.

Drastic differences in color may arise when the same metal ion occurs in different coordinations, as illustrated by the examples of $\mathrm{Co}^{2}+$ (figure 9) and $\mathrm{Fe}^{2+}$ (figure 10). Cobaltocalcite is popular as a collector's item because of its vivid pink color, which is due (as the name suggests) to cobalt; in calcite it is in octahedral coordination as $\mathrm{Co}^{2+}$. "Cobalt blue" spinel derives its vivid color from $\mathrm{Co}^{2+}$ as well. In this case, however, the cobalt is tetrahedrally coordinated, resulting in a striking blue color.

A similar dramatic modification in hue is encountered with $\mathrm{Fe}^{2+}$. The green color of peridot results from the presence of ferrous iron in two slightly distorted octahedral sites, but $\mathrm{Fe}^{2+}$ imparts a deep red color to almandine garnet (Loeffler and Burns, 1976). The basic reason for this difference is the coordination of the $\mathrm{Fe}^{2+}$ ion, which in garnet is a distorted cube (again, see figure 8).

To understand why changes in the geometry of the environment of the ion have such a profound effect on color, we must reconsider the orbitals of the central ion. These orbitals project outward toward the oxygen ions in the coordination environment: Some of the orbitals point directly at these surrounding ions, some fall in between /see figure 11). Electrons in these orbitals of the central ion are electrostatically repelled by the electrons in the neighboring oxygen ions. The intensity of repulsion from the negatively charged oxygen ions 


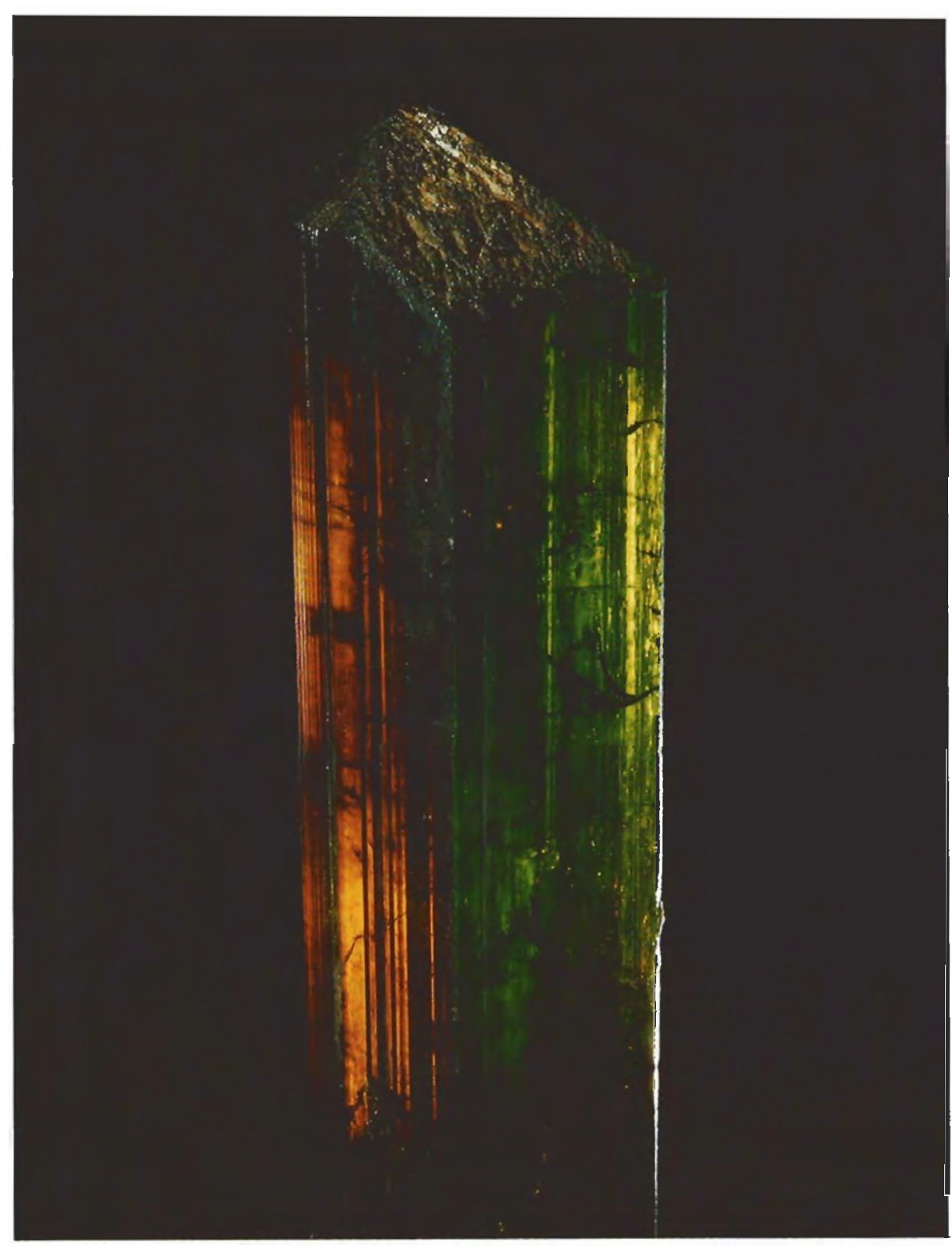

Figure 12. The strong brown-green pleochroism of this 12 -cm-long epidote crystal from Pakistan is thought to be due to a geometric distortion of the octahedral iron site.

Specimen courtesy of the Sorbonne Collection, Paris; photo (C) Nelly Bariand.

depends on the number of oxygen atoms, their distance from the central metal ion, and the particular orbital the electron is in. When an electron in the central ion absorbs light and moves from one orbital to another, the energy required depends on the particular electrostatic repulsion experienced during this move. Consequently, the amount of repulsion will be different in the case of octahedral and tetrahedral environments and, thus, they will produce different colors.
Figure 11. Electrostatic repulsions of different intensities are experienced by electrons in different orbitals of the metal ion, as illustrated here in the case of octahedral coordination. (A) When an orbital of the metal ion points directly toward neighboring oxygen ions, the electrostatic repulsion between the electrons in the orbital and the oxygen ions, both charged negatively, is intense. (B) When an orbital points between oxygen ions, the repulsion is smaller. This difference is ultimately responsible for the different colors that arise from a given ion in different coordination geometry (see figures 9 and 10).

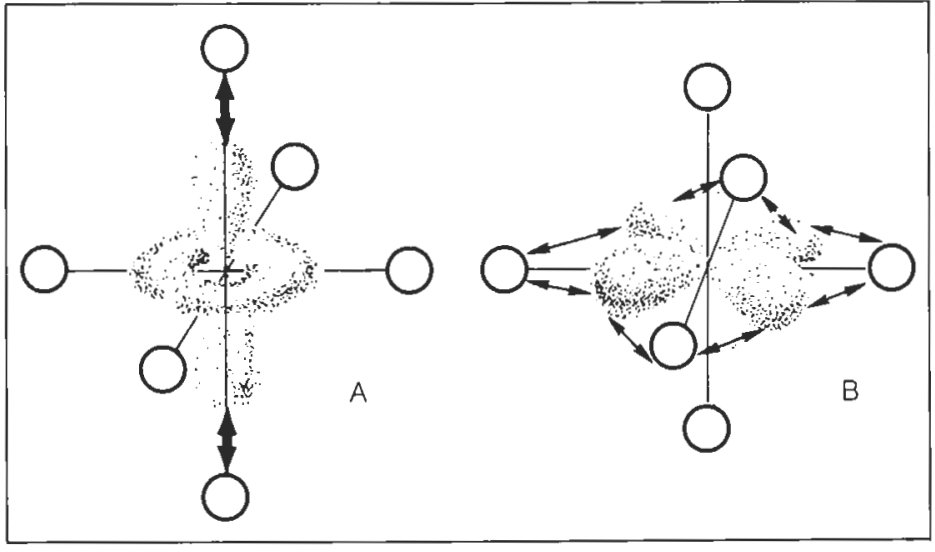


Pleochroism. The color of a gem mineral also depends on its orientation with respect to the light source, sometimes radically. For example, epidote shows brown in one direction and green in another (figure 12). The cause in epidote is that certain electron transitions are favored along certain crystallographic axes. This effect is most prominent in minerals where the octahedral sites are significantly distorted from the ideal geometry. In this case, when an electron moves from one orbital to another, a different amount of energy is required in different orientations. (It must be noted, however, that this is only one origin of pleochroism in gem materials. Strong pleochroism can also be seen in coloration that involves charge-transfer processes or color centers, as will be described in part 2 of this series.)

Influence of the Details of the Coordination Environment. A particular ion, in a single valence state, can produce a variety of colors in different gem materials even though it is surrounded by the same number of oxygen ions. For example, ruby, emerald, and alexandrite all owe their vivid coloration to $\mathrm{Cr}^{3+}$ in octahedral coordination (Loeffler and Burns, 1976). Why, then, do ruby and emerald differ in color, and why does alexandrite show different colors under different light sources? Figure 13 shows the optical absorption spectra of these three minerals. The spectra of both ruby and emerald consist of two large absorption bands in the visible region. The major difference is the exact position of the peaks of the two absorption bands. They are situated at highest energy (shortest wavelength) for ruby, which has two transmission windows - one centered in the blue $(480 \mathrm{~nm})$ between the major absorption bands and one centered in the red (wavelengths longer than $610 \mathrm{~nm}$ ). Because the eye is more sensitive in the red just above $610 \mathrm{~nm}$ than it is in the blue (see figure 3), the ruby appears red (figure 14). On the other hand, the transmission window for emeralds is centered in the green, where the eye is most sensitive, giving the stones their rich characteristic color (figure 15).

The difference between ruby and emerald can be explained by the particulars of the crystallographic environment around chromium. Factors such as the distance between chromium and its neighboring oxygen atoms, and the details of the local geometry, contribute to the local electrostatic field about the chromium. These details are sufficiently different for the two minerals that the absorption features, though similar in shape for

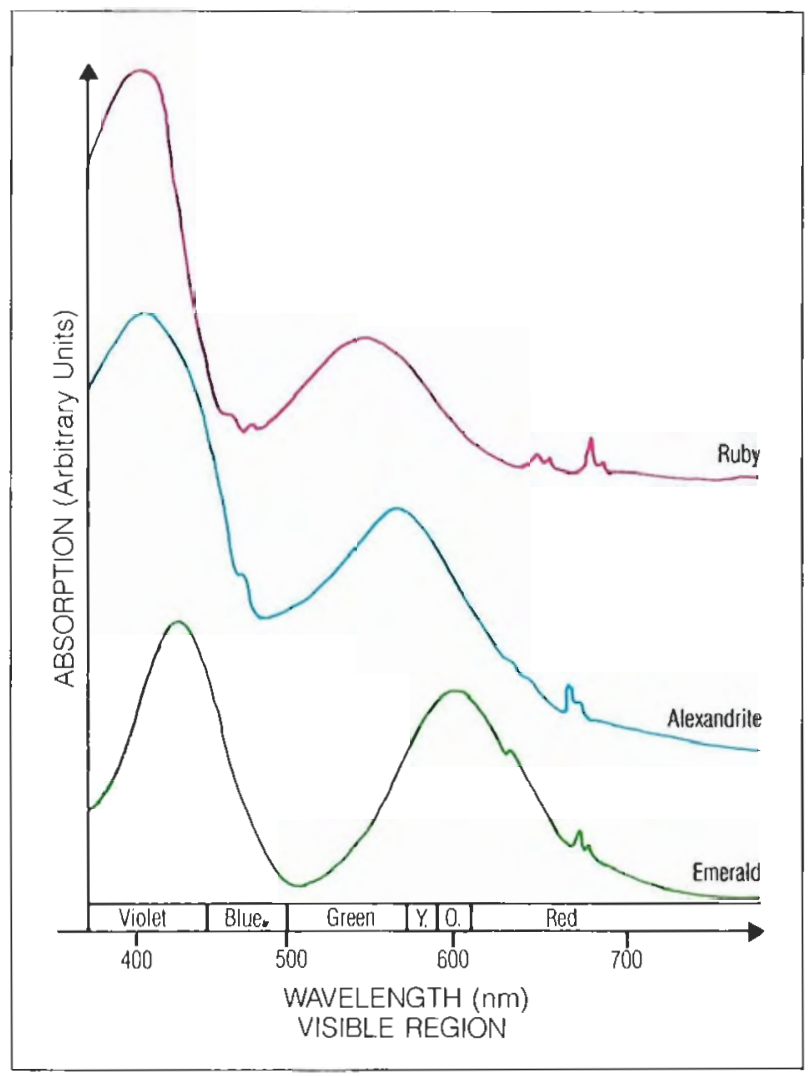

Figure 13. Optical absorption spectra of a ruby from Burma, an alexandrite from Tanzania, and an emerald from Colombia. As the chromium absorption bands shift toward longer wavelengths, the color changes, respectively, from red, to red and green (under different types of light), to green only.

both minerals, will appear at lower energies in beryl than in corundum (again, see figure 13).

In alexandrite, which is one of the chromiumbearing varieties of chrysoberyl, the $\mathrm{Cr}^{3+}$ site is intermediate between those of ruby and emerald. Consequently, alexandrite transmits both bluish green and red (again, see figure 13). In sunlight, it will appear mostly green, because this is where solar light has its maximum intensity and the human eye has its greatest sensitivity. When viewed with incandescent light, however, the stone appears red because incandescent light contains a relatively larger proportion of red than does solar light (an excellent illustration of this color change appears in Koivula, 1987).

As another example, red corundum and green zoisite are both colored by $\mathrm{Cr}^{3+}$ in octahedral coordination, substituting for $\mathrm{Al}^{3}+$ in the crystal structure. The difference in color is due to a 


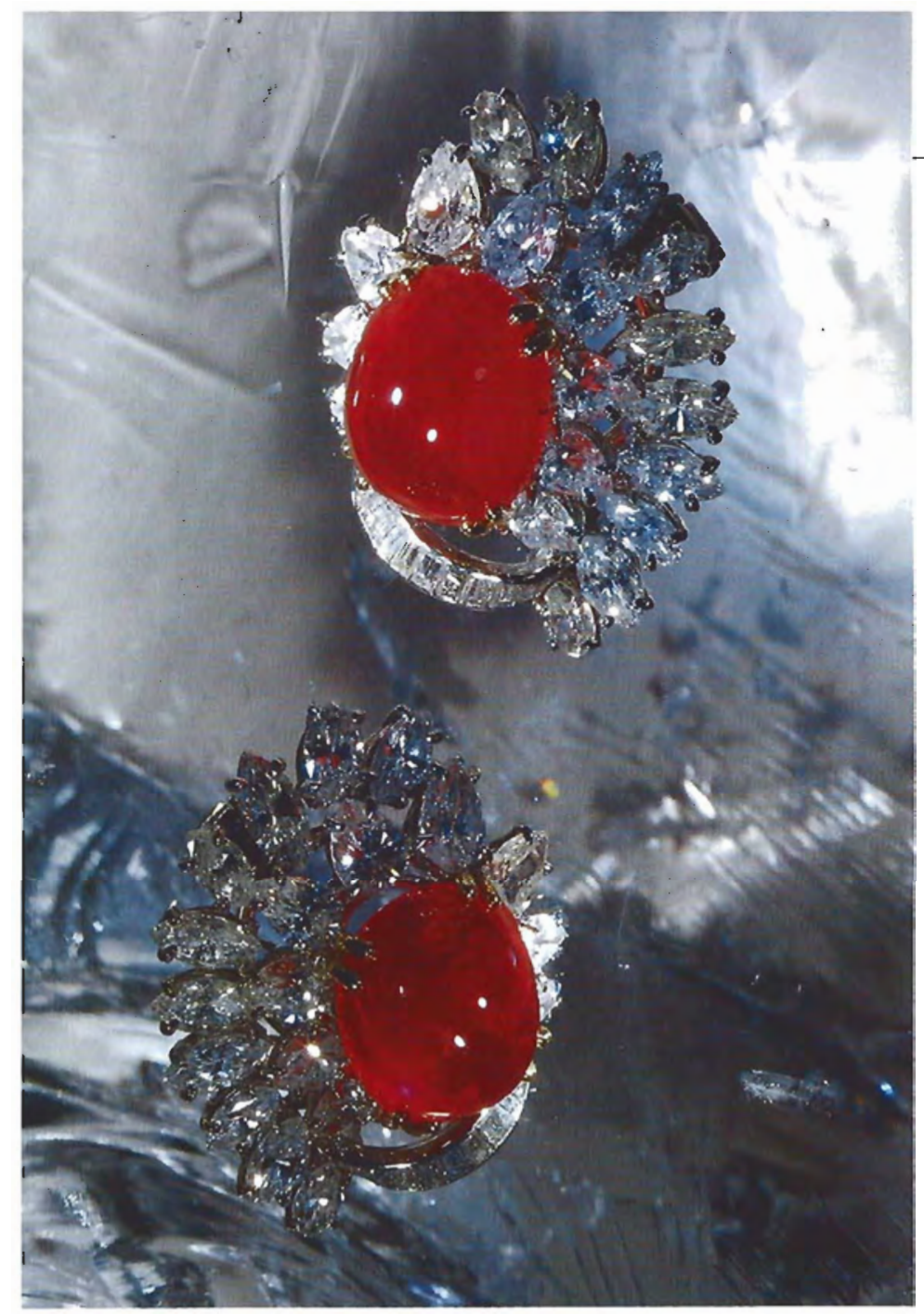

Figure 14. Because of the position of the $\mathrm{Cr}^{3+}$ absorption bands in its visible spectrum, ruby has a red body color. In addition, rubies not only transmit red, but they also emit it, so that their color can be reinforced by the strong red luminescence, especially in Burmese stones. The deep red body color and natural red luminescence of these two 20-ct rubies (set in earrings) is enhanced by the cabochon cut. Courtesy of Collection Chaumet, Paris; photo (c) Nelly Bariand.

difference in the distance between the metal ion (chromium) and the neighboring oxygen atoms. In zoisite structure, $\mathrm{Cr}^{3+}$ occupies a site where the average metal-oxygen distance is I.967 $\AA$ (Dollase, I968). In corundum structure, however, it is much shorter-1.913 $\AA$ (Newnham and De Haan, 1962). Therefore, the $\mathrm{Cr}^{3+}$ ion experiences more electrostatic repulsion in corundum, and its absorption features are shifted to higher energies than in zoisite, causing a contrast in color.

One factor that might influence the environment of a given ion, in particular the metal-oxygen distance, is its concentration. Various authors have observed this "concentration effect" in corundum, spinel, and garnet (e.g., Calas, 1978). In the red MgAl garnet pyrope, $\mathrm{Cr}^{3+}$ ions are present at low concentration, and the $\mathrm{Cr}$-O distance is $1.96 \AA$ (Calas, 1978). In the deep purple $\mathrm{Mg}$ - $\mathrm{Cr}$ garnet knorringite, however, $\mathrm{Cr}^{3+}$ ions occur in the same coordination, but at higher concentration, with a Cr-O distance of $2.03 \AA$ (Berry and Vaughan, 1985). Thus, in a single mineral group, such as garnet, an increase in concentration of $\mathrm{Cr}^{3+}$ will lead to an increase in the $\mathrm{Cr}-\mathrm{O}$ distance and modification of the color from red to purple.

Remarks. The various phenomena that we have described can be approached quantitatively by the use of chemical theories such as crystal field theory (Burns, 1970). These theories can explain the color in gems equally well in the case of either a major constituent / such as iron in peridot and garnet) or a minor component (such as chromium in ruby and emerald). The same type of reasoning can be applied to dispersed metal ions in noncrystalline materials such as glasses; for example, the peridot-like green color of tektites and moldavites is also due to $\mathrm{Fe}^{2+}$. Oversimplifying a little, metal ions create basically the same spectra in glass simulants as in the gems themselves.

Table 1 lists the variety of colors caused by different metal ions in gem materials. When reviewing this list, please keep in mind that many gems are colored by a combination of causes /some of which will be discussed later in this series of articles). For example, the different shades of red in ruby are due to the influence of minor absorptions caused by small amounts of dispersed iron and vanadium ions (Harder, 1969). Also, the same color (e.g., green) can occur in a given gem material (e.g., nephrite) for different reasons (dispersed octahedral $\mathrm{Cr}^{3+}$ produces "emerald-green," while dispersed octahedral $\mathrm{Fe}^{2+}$ gives a more yellowish green).

\section{CONCLUSION}

The first article of this series on the origin of color in gem materials has reviewed the best-known cause of color: absorption of light by dispersed metal ions. We have demonstrated that not only is the identity of the metal ion important, but its valence state, the nature of the neighboring atoms, its coordination, and the details of its environment may also have a dramatic effect on the color of a gem material. The only way treatment can affect a 


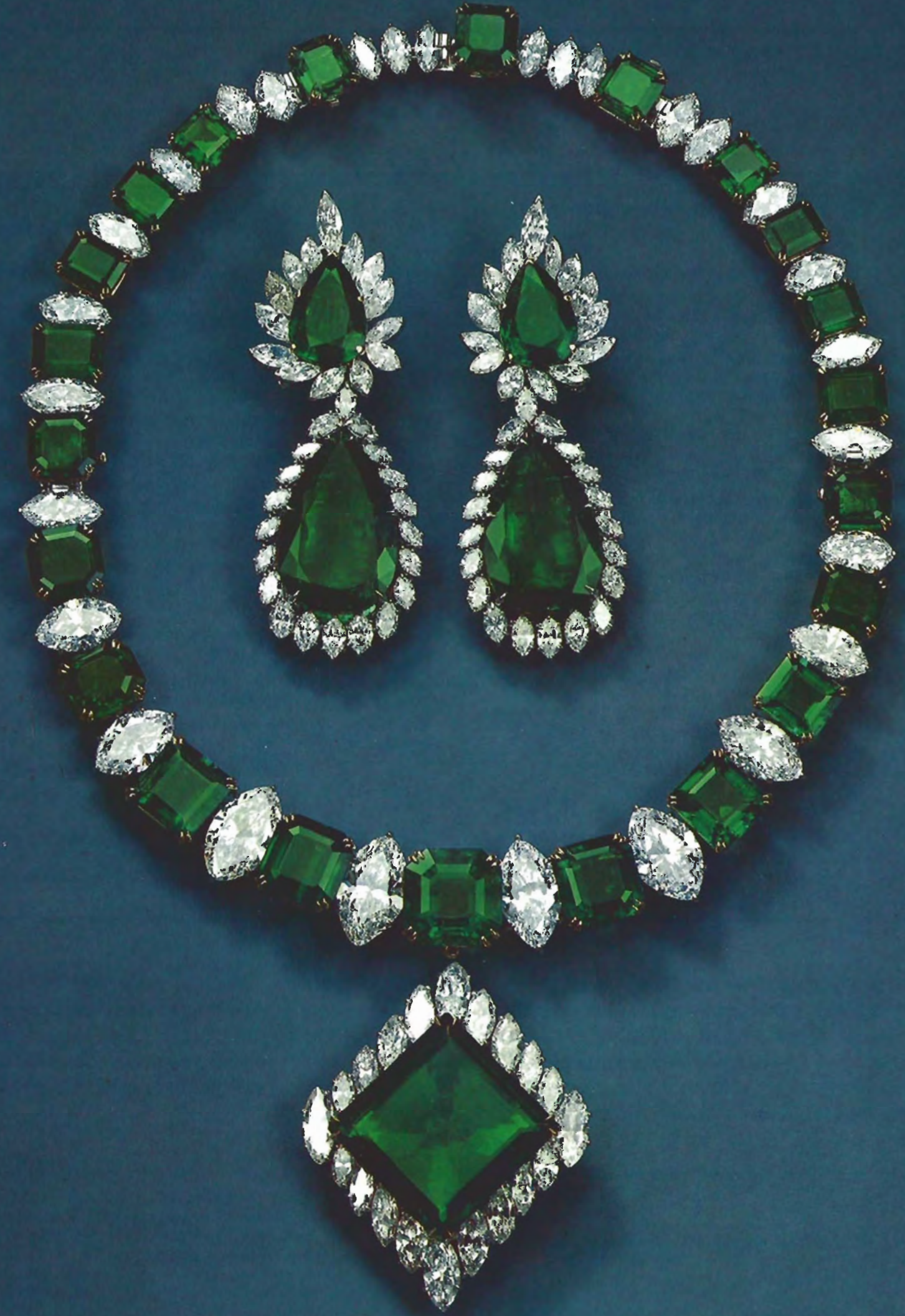

Figure 15. The vivid green of these Colombian emeralds results from the distinctive coordination environment of the color-causing $\mathrm{Cr}^{3+}$ ions. The emerald in the pendant weighs $37 \mathrm{ct}$; the two drops in the earrings weigh a total of $49 \mathrm{ct}$. Jewelry courtesy of Harry Winston, Inc.; photo $\mathbb{O}$ Harold et) Erica Van Pelt. 
TABLE 1. Dispersed metal ions and the colors they cause in various gem materials.

\begin{tabular}{|c|c|c|c|}
\hline $\begin{array}{l}\text { Ion and } \\
\text { coordination }\end{array}$ & Color and gem material & $\begin{array}{l}\text { Ion and } \\
\text { coordination }\end{array}$ & Color and gem material \\
\hline $\begin{array}{l}\mathrm{Ti}^{3+} \\
\text { octahedral }\end{array}$ & $\begin{array}{l}\text { No known gems where the origin of color has } \\
\text { been positively proved to be dispersed } \mathrm{Ti}^{3+} \text {, } \\
\text { although the case of rose quartz is under } \\
\text { discussion (see Cohen and Makar, 1985) }\end{array}$ & $\begin{array}{l}\text { Mn'2+ } \\
\text { octahedral }\end{array}$ & $\begin{array}{l}\text { Pink: beryl/morganite (Woods and Nassau, } \\
\text { 1968); rhodocrosite (Lehmann, 1978); lep- } \\
\text { idolite (Faye, 1968); titanite (Mottana and } \\
\text { Griffin, 1979) }\end{array}$ \\
\hline \multirow[t]{2}{*}{$\begin{array}{l}\text { V4+ } \\
\text { octahedral }\end{array}$} & \multirow{2}{*}{$\begin{array}{l}\text { Blue: zoisite/heat treated = tanzanite } \\
\text { (Hurlbut, 1969) } \\
\text { Green: apophyllite (Rossman, 1974) }\end{array}$} & & $\begin{array}{l}\text { Greenish yellow: some rare elbaites (Ross- } \\
\text { man and Mattson, 1986) }\end{array}$ \\
\hline & & $\mathrm{Mn}^{2+}$ & Orange: spessartine (Manning, 1967a) \\
\hline \multirow{3}{*}{$\begin{array}{l}V^{3+} \\
\text { octahedral }\end{array}$} & \multirow{3}{*}{$\begin{array}{l}\text { Blue: axinite (Schmetzer, 1982) } \\
\text { Brown-violet: zoisite/untreated (Hurlbut, 1969) } \\
\text { Green: beryl/vanadium emerald (Wood and } \\
\text { Nassau, 1968); grossular/tsavorite (Gübelin } \\
\text { and Weibel, 1975); some kyanites, diopsides, } \\
\text { uvites, spodumenes and kornerupines } \\
\text { (Schmetzer, 1982) } \\
\text { Color-change effect: corundum and some } \\
\text { rare pyropes and pyrope-spessartines } \\
\text { (Schmetzer et al., 1980) }\end{array}$} & dist. cubic & \\
\hline & & $\begin{array}{l}\mathrm{Fe}^{3+} \\
\text { octahedral }\end{array}$ & $\begin{array}{l}\text { Yellow: chrysoberyl (Loeffler and Burns, } \\
\text { 1976) } \\
\text { Yellow green: jadeite (Rossman, 1981); epi- } \\
\text { dote (Burns, 1970); andradite (Manning, } \\
\text { 1967b) }\end{array}$ \\
\hline & & $\begin{array}{l}\mathrm{Fe}^{3+} \\
\text { tetrahedral }\end{array}$ & $\begin{array}{l}\text { Yellow: orthoclase and other feldspars } \\
\text { (Hofmeister and Rossman, 1983); sillimanite } \\
\text { (Rossman et al., 1982) }\end{array}$ \\
\hline \multirow[t]{6}{*}{$\begin{array}{l}\mathrm{Cr}^{3+} \\
\text { octahedral }\end{array}$} & \multirow{6}{*}{$\begin{array}{l}\text { Blue: kornerupine (Schmetzer, 1982) } \\
\text { Green: beryl/emerald, spinel (Vogel, 1934); } \\
\text { spodumene/hiddenite, diopside/chrome } \\
\text { diopside, jadeite/chrome jadeite, nephrite, } \\
\text { euclase, andradite/demantoid, some rare } \\
\text { olivines, variscite (Anderson, 1954-55); } \\
\text { titanite/chrome sphene, zoisite (Schmetzer, } \\
\text { 1982); uvarovite (Calas, 1978) } \\
\text { Color-change effect: chrysoberyl/alexandrite } \\
\text { (Farrell and Newnham, 1965); some pyropes } \\
\text { (Schmetzer et al., 1980) } \\
\text { Red to violet: corundum/ruby, spinel (Vogel, } \\
\text { 1934); some pyrope (Manning, 1967a); } \\
\text { taaffeite (Schmetzer, 1983); topaz } \\
\text { (Anderson, 1954-55); stichtite }\end{array}$} & $\begin{array}{l}\mathrm{Fe}^{2+} \\
\text { octahedral }\end{array}$ & $\begin{array}{l}\text { Blue: elbaite/indicolite (Dietrich, 1985) } \\
\text { Yellowish green to green: olivine/peridot } \\
\text { (Loeffler and Burns, 1976); diopside, } \\
\text { actinolite/nephrite (Burns, 1970); natural } \\
\text { glasses/moldavite, tektite (Pye et al., 1983) }\end{array}$ \\
\hline & & $\begin{array}{l}\mathrm{Fe}^{2+} \\
\text { tetrahedral }\end{array}$ & $\begin{array}{l}\text { Blue: gahnite and "gahnospinel" (Dickson and } \\
\text { Smith, 1976) }\end{array}$ \\
\hline & & $\begin{array}{l}\mathrm{Fe}^{2+} \\
\text { dist. cubic }\end{array}$ & $\begin{array}{l}\text { Red: pyrope, pyrope-almandine (rhodolite), } \\
\text { almandine (Manning, 1967a) }\end{array}$ \\
\hline & & $\begin{array}{l}\mathrm{Co}^{2+} \\
\text { octahedral }\end{array}$ & $\begin{array}{l}\text { Pink: calcite/cobaltocalcite (Webster, 1970) } \\
\text { Green: sphalerite (Marfunin, 1979) }\end{array}$ \\
\hline & & $\begin{array}{l}\mathrm{Co}^{2+} \\
\text { tetrahedral }\end{array}$ & $\begin{array}{l}\text { Blue: spinel (Shigley and Stockton, 1984); } \\
\text { staurolite (Cech et al., 1981) }\end{array}$ \\
\hline & & $\mathrm{Ni}^{2+}+$ & Green: clay inclusions in chrysoprase and \\
\hline \multirow[t]{2}{*}{$\begin{array}{l}\mathrm{Mn}^{3+} \\
\text { octahedral }\end{array}$} & \multirow{2}{*}{$\begin{array}{l}\text { Red to violet to pink: beryl/red beryl } \\
\text { (Shigley and Foord, 1984); piemontite (Burns, } \\
\text { 1970); some elbaites/rubellites, sugilite } \\
\text { (Shigley et al., 1987); rhodonite (Gibbons et } \\
\text { al., 1974); zoisite/thulite } \\
\text { Green: andalusite/viridine (Smith et al., 1982) }\end{array}$} & octahedral & $\begin{array}{l}\text { some opals, e.g., prase opal (Koivula and } \\
\text { Fryer, 1984) }\end{array}$ \\
\hline & & $\begin{array}{l}\mathrm{Cu}^{2+} \\
\text { octahedral }\end{array}$ & $\begin{array}{l}\text { Blue: turquoise and chrysocolla (Lehmann, } \\
\text { 1978); azurite (Marfunin, 1979) } \\
\text { Green: malachite and dioptase (Lehmann, } \\
\text { 1978) }\end{array}$ \\
\hline
\end{tabular}

color caused by dispersed metal ions is by modifying the valence state. In recent years, we have become aware of the importance of other types of coloration, such as charge transfer and color centers. Heat treatment can induce or increase charge transfers, and irradiation often creates color cen- ters. These two causes of color will be examined and illustrated with a number of examples in the next article in this series. The least common origins of color in gem materials, band theory and physical optics, will be discussed in the third and last part.

\section{REFERENCES}

Anderson B.W. (1954-55) The spectroscope and its applications to gemmology, parts 10 to 17. The Gemmologist, Vol. 23, Nos. 275-282.

Balitsky V.S., Balitskaya O.V. (1986) The amethyst-citrine dichromatism in quartz and its origin. Physics and Chemistry of Minerals, Vol. 13, pp. 415-421.

Berry F.J., Vaughan D.J., Ed. (1985) Chemical Bonding and Spectroscopy in Mineral Chemistry. Chapman and Hall, New York.

Bill H., Calas G. (1978) Color centers, associated rare-earth ions and the origin of coloration in natural fluorites. Physics and Chemistry of Minerals, Vol. 3, pp. 117-131.

Burns R.G. (1970) Mineralogical Applications of Crystal Field Theory. Cambridge Earth Science Series, Cambridge University Press, Cambridge, England.

Calas G. (1978) Le chrome et la couleur des minéraux: Un exemple "pédagogique." Revue de Gemmologie a.f.g., Vol. 54, pp. 6-8.

Cech F., Povondra P., Vrana S. (1981) Cobaltoan staurolite from Zambia. Bulletin de Minéralogie, Vol. 104, pp. 526-529.

Cohen A.I., Makar L.N. (1985) Dynamic biaxial absorption spectra of $\mathrm{Ti}^{3}+$ and $\mathrm{Fe}^{2}+$ in a natural rose quartz crystal. Mineralogical Magazine, Vol. 49, pp. 709-715.

Dickson B.L., Smith G. (1976) Low temperature optical absorp- 
tion and Mossbauer spectra of staurolite and spinel. Canadian Mineralogist, Vol. 14, pp. 206-215.

Dietrich R.V. (1985) The Tourmaline Group. Von Nostrand Reinhold Co., New York.

Dollase W.A. (1968) Refinement and comparison of the structurcs of zoisite and clinozoisite. American Mineralogist, Vol. 53, pp. 1882-1898.

Duplessis Y., Ed. (1985) Les Couleurs Visibles et Non Visibles. Editions du Rocher, Paris.

Farge Y., Fontana M.P. (1979) Electronic and Vibrational Properties of Point Defects in Ionic Crystals. North Holland Publishing, Amsterdam.

Farrell E.F., Newnham R.E. (1965) Crystal field spectra of chrysoberyl, alcxandrite, peridot and sinhalite. American Mineralogist, Vol. 50, pp. 1972-1981.

Faye G.H. (1968) The optical absorption spectra of certain transition metal ions in muscovite, lepidolite and fuchsite. Canadian Journal of Earth Sciences, Vol. 5, pp. 31-38.

Fritsch E. (1985) La couleur des minéraux et des gemmes. Première partie: Des tribulations d'un électron à l'intérieur d'un atome isolé. Monde Minéraux, Vol. 67, pp. $20-25$.

Fyfe W.S. (1964) Geochemistry of Solids. McGraw-Hill Book Co., New York.

Gibbons R.V., Ahrens T.J., Rossman G.R. (1974) A spectrographic interpretation of shock-produced color change in rhodonite $\left(\mathrm{MnSiO}_{3}\right)$ : The shock-induced reduction of $\mathrm{Mn}(\mathrm{Ill})$ to $\mathrm{Mn}(\mathrm{II})$. American Mineralogist, Vol. 59, pp. $177-182$.

Goldman .D.S., Rossman G.R., Parkin K.M. (1978) Channel constitutents in beryl. Physics and Chemistry of Minerals, Vol. 3 , pp. 225-235.

Gübelin E.J., Weibel M. (1975) Green vanadium grossular garnet from Lualenyi, near Voi, Kenya. Lapidary Journal, Vol. 29 pp. $402-426$.

Harder H. (1969) Farbgebende Spurenelemente in den natürlichen Korunden. Neues Jahrbuch für Mineralogie Abhandlungen, Vol. 110, No. 2, pp. 128-141.

Hofmeister A.M., Rossman G.R. (1983) Color in feldspars. In P.H. Ribbe, Ed., Reviews in Mineralogy, Vol. 2, 2nd ed.: Feldspar Mineralogy, Mineralogical Society of America, Washington, DC, pp. 271-280.

Hurlbut C.S. (1969) Gem zoisite from Tanzania. American Mineralogist, Vol. 54, pp. 702-709.

Kittel C. (1956) Introduction to Solid State Physics, John Wilcy \& Sons, New York.

Koivula J.I. (1987) Gem news. Gems \&) Gemology, Vol. 23, No. 2, pp. $122-124$

Koivula J.l,, Fryer C.W. (1984) Green opal from East Africa. Gems @emology, Vol. 20, No. 4, pp. 226-227.

Kunz G.F. \{1913) The Curious Lore of Precious Stones. Reprinted by Dover Publications, New York, 1971.

Lehmann G. (1978) Farben von Mineralien und ihre Ursachen. Fortschritte der Mineralogie, Vol. 56, No. 2, pp. 172-252.

Loeffler B.M., Burns R.G. (1976) Shedding light on the color of gems and minerals. American Scientist, Vol. 64, pp. 636-647.

Manning P.G. (1967a) The optical absorption spectra of the garnets almandine-pyrope, pyrope and spessartine and some structural interpretations of mineralogical significance. Canadian Mineralogist, Vol. 9, No. 2, pp. 237-251

Manning P.G. (1967b) The optical absorption spectra of some andradite and the identification of the $\left.{ }^{6} \mathrm{~A}_{1} \rightarrow{ }^{4} \mathrm{~A}_{1}{ }^{4} \mathrm{E} / \mathrm{G}\right)$ transition in octahedrally bonded $\mathrm{Fe}^{3+}$. Camadian Journal of Earth Sciences, Vol. 4, pp. 1039-1047.

Marfunin A.S. (1979) Physics of Minerals and Inorganic Materials, an Introduction. Transl. by N.G. Egorova and A.G. Mishchenko, Springer Verlag, Berlin.
Mottana A., Griffin W.L. \{1979) Pink titanite (greenovitel from St. Marcel, Valle D'Aosta, Italy. Rendiconti Società Italiana di Mineralogia e Petrologia, Vol. 35, No. 1, pp. $135-143$.

Nassau K. (1975) The origin of color in gems and minerals. Gems \&emology, Vol. 15, pp. 2-11.

Nassau K. (1983) The Physics and Chernistry of Color: The Fifteen Causes of Color. John Wiley \& Sons, New York,

Nassau K. (1984) Gemstone Enhancement. Butterworths, Stoneham, MA.

Newnham R.E., De Haan Y.M. (1962) Refinement of the $\alpha \mathrm{Al}_{2} \mathrm{O}_{3}, \mathrm{Ti}_{2} \mathrm{O}_{3}, \mathrm{~V}_{2} \mathrm{O}_{3}$ and $\mathrm{Cr}_{2} \mathrm{O}_{3}$ structures. Zeitschrift für Kristallographie, Vol. 117, pp. 235-237.

Novak G.A., Gibbs G.V. (1971) The crystal chemistry of the silicate garnets. American Mineralogist, Vol. 56, pp. $791-825$.

Pouget (1752) Traité des Pierres Précieuses. As cited in P. Bariand and J. P. Poirot (1985) Larousse des Pierres Précieuses, Larousse, Paris.

Pye L.D., O'Keefe J.A., Fréchette V.D., Eds., (1984) Natural Glasses. North Holland Publishing, Amsterdam.

Romeijn F.C. (1953) Physical and crystallographical properties of some spinels. Philips Research Reports, Vol. 8, pp. 304-320.

Rossman G.R. (1974) Optical spectroscopy of green vanadium apophyllite from Poona, India. American Mineralogist, Vol. 59, pp. 62l-622.

Rossman G.R. (1981) Color in gems: The new technologies. Gems (4) Gemology, Vol. 17, pp. 60-71.

Rossman G.R., Grew E.S., Dollase W.A. (1982) The colors of sillimanite. American Mineralogist, Vol. 67, pp. 749-761.

Rossman G.R., Mattson S.M. (1986) Yellow, manganese-rich elbaite with manganese-titanium intervalence charge transfer. American Mineralogist, Vol. 71, pp. 599-602.

Schmetzer K., Bank H., Gübelin E. (1980) The alexandrite effect in minerals: Chrysoberyl, garnet, corundum, fluorite. Neues Jahrbuch für Mineralogie Abhandlungen, Vol. 138 , pp. 147-164.

Schmetzer K. (1982) Absorptionsspektroskopie und Farbe von $\mathrm{V}^{3+}$ - haltigen natürlichen Oxiden und Silikaten-ein Beitrag zur Kristallchemie des Vanadiums. Neues Jahrbuch für Mineralogie Abhandlungen, Vol. 144, pp. 73-106.

Schmetzer K. (1983) Crystal chemistry of natural Be-Mg-Aloxides: taaffeite, taprobanite, musgravite. Neues Jahrbuch für Mineralogie Abhandlungen, Vol. 146, No. 1, pp. 15-28.

Shigley J.E., Stockton C.M. (1984) "Cobalt-blue" gem spinels. Gems (4) Gemology, Vol. 20, pp. 34-41.

Shigley J.E., Foord E.E. (1984) Gem-quality red beryl from the Wah-Wah Mountains, Utah. Gems \&) Gemology, Vol. 20, No. 4, pp. 208-221

Shigley J.E., Koivula J.I., Fryer C.W. (1987) The occurrence and gemological properties of Wessels Mine sugilite. Gems 4 ) Gemology, Vol. 23, No. 2, pp 78-90.

Smith G., Hålenius U., Langer K. (1982) Low temperature spectral studies of $\mathrm{Mn}^{3+}$-bearing andalusite and epidote type minerals in the range $30000-5000 \mathrm{~cm}^{-1}$. Physics and Chemistry of Minerals, Vol. 8, pp. 136-142.

Vogel P. (1934) Optische Untersuchungen am Smaragd und einigen anderen durch Chrom gefärbten Mineralien. Neues Jahrbuch für Mineralogie, Geologie und Paleontologie, Vol. A68, pp. 401-438.

Wasserman J.S. (1978) Color Vision. John Wiley \& Sons, New York.

Webster R. (1983) Gems, Their Sources, Descriptions and Identification. Butterworths, London.

Wood D.L., Nassau K. (1968) The characterization of beryl and emerald by visible and infrared absorption spectroscopy American Mineralogist, Vol. 53, pp. 777-800. 